\title{
A Study of Metadiscourse Identification Ability in Chinese English Majors with Different Oral Proficiency in Shandong Province
}

\author{
Mingyue Sun \\ Department of Applied Linguistics, National University of Ireland, Cork, T37 F8HK, Ireland
}

\begin{abstract}
In the field of foreign language teaching in China, the weakness of oral English teaching is one main obstacle in college. In terms of previous studies, metadiscourse as a relatively young specialization has been frequently employed in foreign language teaching in the last thirty years. The importance of interactive and interactional metadiscourse in organizing, interpreting, and evaluating the texts is accepted by many linguistics. Various studies have shown that metadiscourse plays a key role in a range of genres and settings, including research article abstracts, academic writing, reading and all kinds of dissertation. However, few studies have given support to the use of metadiscourse in oral language field, especially in English oral teaching field. Thus, this study mainly combines quantitative analysis with previous theoretical studies of metadiscourse to explore the overall pattern of metadiscourse identification ability (MIA) in Chinese English majors in Shandong Province. With reference to the various MIA features of Chinese students, this study further expounds the correlation between students' MIA and their oral proficiency level.

This experimental study involves 120 Chinese English majors in four universities in Shandong Province of China. To explore MIA in the subjects, the researcher designs a test paper based on previous authentic tests and IELTS conversation recordings. All recognized metadiscourse markers are collected and recorded by the researcher. Each type and number of recognized metadiscourse are then put into the computer and processed by statistic software Excel and SPSS, including a $t$-test. The results of the study show that the overall MIA of Shandong English majors is not as satisfying as we expect. Besides, there is a correlation between MIA and the students' oral proficiency in terms of the number and types of metadiscourse markers. More specifically, higher oral proficiency students can recognize more metadiscourse markers compared with lower oral proficiency students and there is an obvious distinction in interactional metadiscourse awareness between the two groups of informants. Therefore, it is required to sensitize Shandong students to the functions of metadiscourse so that they can perform in oral contexts and further practical suggestions can be provided for the improvement of oral English teaching in Shandong universities.
\end{abstract}

Keywords: metadiscourse identification ability (MIA), oral proficiency, Shandong English majors

\section{Introduction}

According to Hyland (2000), Metadiscourse is seen as a construct grounded means of facilitating communication and understanding of discourse as a form of social engagement. Along with such increasing recognition of its important functions in connecting and organizing discourse, there has been an explicit goal in College English Curriculum Requirement (2011), which aims to train students' language ability in authentic environments on the premise of emphasizing metadiscourse knowledge. Based on a review of studies, language communication usually includes two levels (see Fang \& Liu, 2015; Ding, 2009) of which we focus on the metadiscourse level that the message senders do not add propositional material, but guide and direct the audience to organize, interpret, evaluate, and react to such material which means to make students more sensitive to the possibility that the potential readers and listeners may have more specific needs than most of them can imagine.

A number of studies have been conducted on the theoretical aspect of metadiscourse, including interpreting the definitions and classifications of metadiscourse from different perspectives. Other studies have concentrated on academic value of metadiscourse, ranging from academic writing, dissertation, and research abstracts to news reports as well as contrastive analysis of cross-cultural national newspapers.

However, experimental studies of metadiscourse have some limitations and therefore provide a significant point for my own study. To start with, most studies about metadiscourse are concentrated on its value in written form of discourse, especially showing a tendency towards formal and scientific genre. The fact is that an investigation into 
English learning of college freshmen conducted by Cai in 2005 have shown that $37.53 \%$ of respondents admit that oral English is the most difficult part of English learning, while listening and reading just occupy $17.68 \%$ and $12.10 \%$ respectively. Furthermore, Li and Pang (2009) have noted that lack of knowledge in metadiscourse for most English teachers is the main factor that affects oral English teaching in college according to few experimental studies on the value of metadiscourse in oral English. Accordingly, this study intends to explore the overall MIA of Chinese English majors in Shandong Province based on quantitive analysis of collected testing data in this research and focuses on the importance of metadiscourse in oral communication.

Secondly, compared with native speakers, Chinese English majors showed excessive, inappropriate and monotonous use of metadiscourse in oral communication (Xin, 2009). This is partially because most English majors do not clearly know what metadiscourse is not to mention the appropriate utilization of it. Hereby, this study emphasizes on metadiscourse knowledge and shows the differences in MIA among Chinese English majors with different oral proficiency.

Finally, metadiscourse is an open architected framework in discourse which means it contains multiple constructed items, from single word, phrase, sentence, and passage and even to the non-linguistic elements such as punctuation mark, dash, and graphology of discourse (Li \& Pang, 2009). It is difficult for researchers to mix all these constituent factors into one research model, as a consequence this study mainly focuses on single words and phrases of metadiscourse in oral materials and explores general features of MIA in Chinese English majors in Shandong Province with their different oral proficiency.

As can be seen from the above, this study can effectively show us specific number and type of MIA of Shandong Province English majors with their different oral proficiency and consequently present the great value of metadiscourse knowledge to language teachers that could encourage students to speak more coherently, to convey propositional information more smoothly, and eventually to facilitate their communication.

\section{Methodology}

\subsection{Subjects}

In undertaking this specific research, in total, 160 (get rid of 34 insufficient data, 120 actually) third-year English majors from four normal university in Shandong Province are chosen as subjects of this experimental study. The specific selection procedures of subjects are as follows:

To start with, the researcher asked for English oral exam scores of the whole junior English majors in TEM-4 Oral Test from the Academic Affairs Office of the universities being investigated (TEM-4, Test for English Majors-Band 4). The total number of junior English majors was 756 among which includes Excellent (20), Good (145), Pass
(406), Fail (185). Next, according to their performance in TEM-4 Oral Test, the researcher chose 80 juniors whose rating is Good and another 80 juniors whose rating is Fail. Among which, 40 informants (20 with Good and 20 with Fail) were requested from each university in Shandong Province. In order to demonstrate this particular MIA analysis, all chosen subjects were therefore divided into two levels - Level A (Pass) with higher oral proficiency and Level B (Fail) with relatively lower oral proficiency. It is worth mentioning that due to the authority of TEM-4 in English Exam System of China, it is confirmed that the performance of the separate students under investigation exhibit significant differences in their oral proficiency level.

However, in the actual process of testing surveys, 16 students did not write their names on the paper; 18 of the subjects gave up completing their tests. As a result, 120 validated test papers were collected with 60 Level A and 60 Level B testing papers in total.

\subsection{Research Instruments}

In order to conduct this experimental research, the primary tool for exploring MIA of students in terms of their different oral proficiency becomes a key point of this study. Test papers with oral texts were selected and extracted from transcript conversations of English speakers to perform this measurement. The test paper (see Appendices) was adapted from Cambridge English IELTS 6-9 Listening and Speaking Section 1 to 4 respectively. All oral materials were transcripted from conversations of native speakers. Section 1 and 2 mainly deal with daily talking about counseling information, job hunting, public service, asking for directions and so forth. However, Section 3 and 4 are mostly related to formal conversations, such as academic seminar, module courses, tourism interpretation and discussion about financing, building and various social projects.

The test for this experiment was made up of two parts: Part one was relatively more distinguishable and provided informants with a guided access to metadiscourse identification in regard to separate short sentences extracted from native speaker discourse. Subjects were requested to underline key phrases or single words which they believed to be useful in promoting discourse coherence and cohesion in specific oral contexts. Part two was selected from complete conversations of English speakers with large amounts and various types of metadiscourse that were available for subjects to identify. It is noted that the difficulty of the test is in its cumulative progression by arrangements of the above two parts. To be specific, part one guided subjects to proceed in an orderly way to be conscious of the actual function of metadiscourse in oral context by providing them with general forms of metadiscourse without any prompt; part two provides further resources for subjects to identify metadiscourse in oral materials without guidance.

All designs of test papers for measuring MIA were derived from Zhang and Guo's testing system in Chunks 
Identification Test (Zhang, 2008; Guo, 2009) which was intended to explore the correlation between students' identification of prefabricated chunks and second language acquisition. In order to record the condition of chunks identification, they requested subjects to underline phrases, strings of words (more than two) that were fixed, semi-fixed from what they learned, treated or used as an individual unit of meaning that tends to be the particularly prefabricated chunks their studies discussed. According to the findings of the tests, they concluded that students with higher levels of second language proficiency are inclined to identify more prefabricated chunks.

Therefore, in terms of their tests, the researcher of the current study utilized the same examination system to explore MIA in the subjects. The question here was that in order to measure MIA in Chinese students through test papers, subjects should not be informed any prompt of metadiscourse itself

\subsection{Data Collection}

The data of this study came from the following two resources.
Firstly, TEM-4 Oral Test achievements of all selected English majors were given by an official institution of investigated universities called Academic Affair Institution Among which the researcher strictly selected 120 students for this empirical study, including 60 Good and 60 Fail students, and they were marked respectively with their name anonymous.

Secondly, the investigated oral texts in a test paper were totally in length of 1,101 words encompassing 100 metadiscourse markers. Test papers were distributed in classes of the subjects without grouping under the assistance of postgraduate students from distinct universities. After testing, the researcher classified test papers in terms of their oral proficiency and divided them into two groups - group A with high oral proficiency and group B with relatively lower oral proficiency. When conducting the test, subjects were requested to underline chunks of metadiscourse independently and not allowed to consult dictionary or any form of lexical references. For affirming the paper, we employ a scheme of metadiscourse which was established in terms of the specific classification of Hyland and Tse (2004) shown in the Table 1.

Table 1 Metadiscourse scheme for oral texts

\begin{tabular}{|l|l|l|l|}
\hline Category of Metadiscourse Markers & $\begin{array}{l}\text { Number } \\
\text { of words }\end{array}$ & $\begin{array}{l}\text { Recognized } \\
\text { words }\end{array}$ & \% of total \\
\hline Interactive (Total) & 6000 & & \\
\hline Transitions & 1200 & & \\
\hline Frame-markers & 1200 & & \\
\hline Endophoic Markers & 1200 & & \\
\hline Evidential-markers & 1200 & & \\
\hline Code-glosses & 1200 & & \\
\hline Interactional (Total) & 6000 & & \\
\hline Hedges & 1200 & & \\
\hline Boosters & 1200 & & \\
\hline Attitude-markers & 1200 & & \\
\hline Engagement-markers & 1200 & & \\
\hline Self-mentioned & 1200 & & \\
\hline Grand totals & 12000 & & \\
\hline
\end{tabular}

After grading the test papers of subjects, firstly the researcher recorded their overall identified metadiscourse without grouping and put the data into Table 1; secondly, the researcher grouped them and counted up the divergent types of metadiscourse in each group (A and B) to show the proportion of each type of metadiscourse that can be identified in whole and put the results into pie chart.

For the perspective of data analysis, quantitative research here mainly applied for computer software Excel and SPSS (Statistical Package for the Social Science) that offered the group description of MIA of English majors and relationships between oral proficiency of Shandong English majors and their MIA in oral contexts. Thus, data analysis here consisted of three parts. Firstly, it was used to display the overall pattern of MIA of Shandong English majors (reflected by counting identified metadiscourse markers in the above test and the following chart). Secondly, it was employed to measure whether there was any difference in divergent types of MIA in terms of different oral proficiency of the students (reflected by the chart). 


\section{Results Analysis and Discussion}

\subsection{Overall Pattern of English Majors' MIA}

Many researchers and scholars (e.g. He, 2011) have found that there are obvious differences between native English speakers and EFL learners in terms of using metadiscourse in their oral output, which is recognized as a crucial factor in affecting English oral production qualities. From 120 test data the researcher collected here illustrates the basic features and tendency of MIA in English majors. The data are presented in the following Table 2:

Table 2: Identified metadiscourse in the test

\begin{tabular}{|c|c|c|c|}
\hline $\begin{array}{c}\text { Category of Metadiscourse } \\
\text { Markers }\end{array}$ & Number of words & $\begin{array}{c}\text { Recognized } \\
\text { words }\end{array}$ & $\begin{array}{c}\text { \% of recognized } \\
\text { total }\end{array}$ \\
\hline Interactive (Total) & 6000 & 4228 & 59.62 \\
\hline Transitions & 1200 & 968 & 13.65 \\
\hline Frame-markers & 1200 & 1052 & 6.43 \\
\hline Endophoic Markers & 1200 & 456 & 11.20 \\
\hline Evidential-markers & 1200 & 794 & 13.51 \\
\hline Code-glosses & 1200 & 958 & 40.38 \\
\hline Interactional (Total) & 6000 & 2864 & 8.32 \\
\hline Hedges & 1200 & 590 & 6.94 \\
\hline Boosters & 1200 & 492 & 7.36 \\
\hline Attitude-markers & 1200 & 522 & 7.08 \\
\hline Engagement-markers & 1200 & 502 & 10.69 \\
\hline Self-mentioned & 1200 & 758 & 100.00 \\
\hline Grand totals & 12000 & 7092 & \\
\hline
\end{tabular}

As the table shows that in oral context, interactive metadiscourse $(59.62 \%$ of the total) are recognized more easily than interactional metadiscourse $(40.38 \%$ of the total) in this test. According to Hyland (2005), interactive metadiscourse tends to be used as basic linguistic resources by speakers and authors, aiming to guide their counterparts by organizing discourses, rather than positioning a perspective or attitude towards the proposition as interactional metadiscourse do. From the data we can see that, it may be easier for students to identify more interactive metadiscourse markers due to the fact that learning materials of Shandong English majors in college tend to adopt interactive metadiscourse to organize texts which is in accordance with the formal and objective stylistic features of such types of genre.

Moreover, by exploring L1 Mandarin undergraduates' writings in English, Ting \& Wharton (2012) have found that both their control Chinese groups employ more interactive metalingual resources than interactional resources in English writings $(62.06 \%$ contrasted with $37.94 \%$ ). Under the imbalanced situation in Chinese English learning which emphasizes reading and writing more importantly than speaking due to the lack of practical communication with foreigners, students are potentially more likely to contact more interactive metadiscourses recourses than interactional ones.

To improve the serious issue aforementioned, on one hand, English educators in Shandong need to be aware of the importance of metadiscourse in oral output. As Halliday stated repeatedly that when people use language, we always try to fulfill three 'macro-functions' of language, that is we work forward to "give expression to experience, interact with audience, and organize expression into a cohesive and coherent text" (as cited from Vande Kopple, 1985: 85). English teachers in Shandong universities are supposed to pay more attention to interactional resources training in oral classes, including emphasizing metadiscourse as mediator between illocutionary partners to express their perspectives, personal feelings as well as being sensitive to mutual social responses in conversation. 


\subsection{Group Differences in MIA}

\subsubsection{Features of Higher Oral Proficiency Learners}

The following Figure 1 is to indicate the distribution of identified metadiscourse markers in oral materials by informants with higher oral proficiency. In general, the proportion in the chart shows that types and numbers of identified metadiscourse markers in the informants are relatively balanced. The differences of two polar markers in this research tend to be only $6 \%$ (with highest $13 \%$ and lowest $7 \%$ ). Moreover, the most frequent identified types of metadiscourse concentrate on transitions, code glosses and frame markers (account for $13 \%, 12 \%$, and $12 \%$ respectively). On the contrary, the markers of endophoic (only occupy $7 \%$ in total) and other three markers, including self-mentioned, engagements and attitudes (all occupy 8\% in total) are not easy to identity for Shandong English majors in this study.

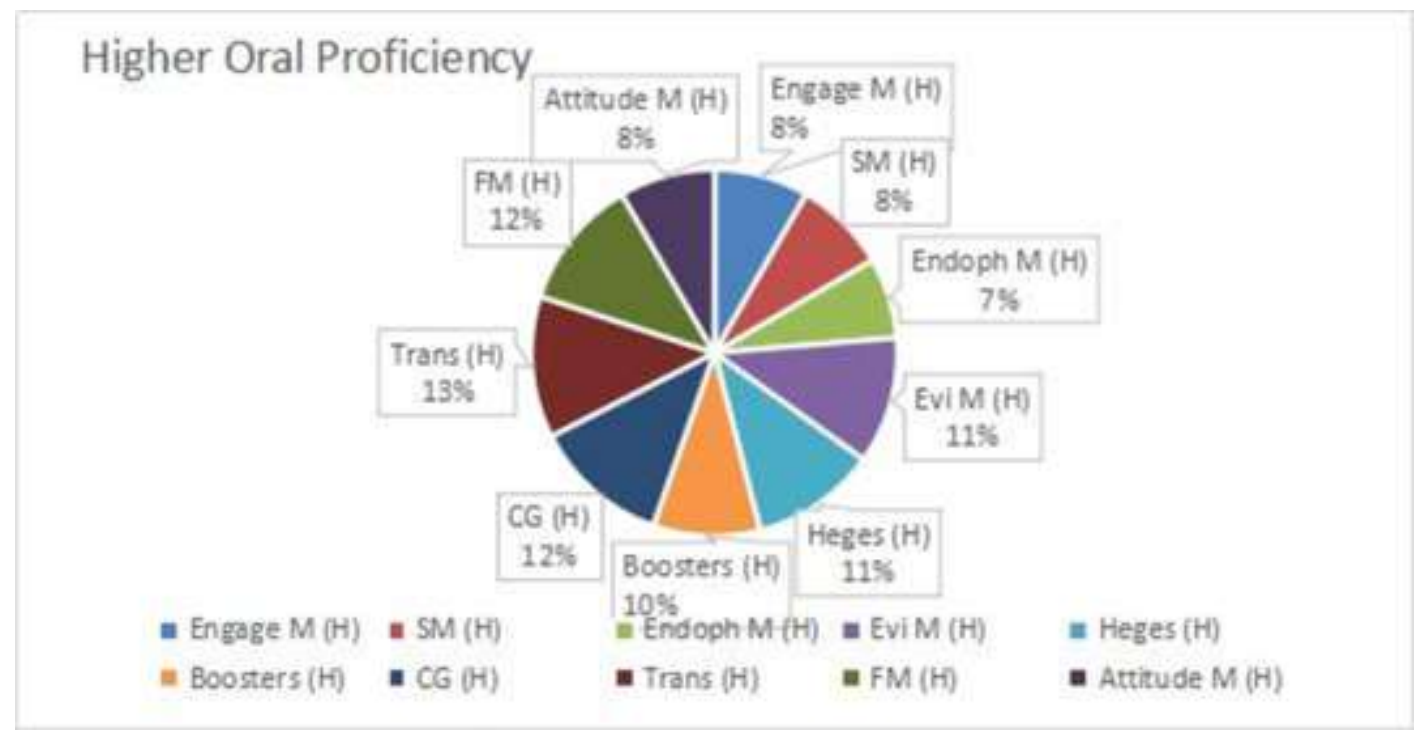

Figure 1: Proportion of identified metadiscourse markers in the test

It is worthwhile noticing that for higher oral proficiency English majors, the most frequent identified ones tend to be transitions, code glosses and frame markers. On one hand, since the influence of Krashen's Input Theory in 1970s, most Chinese English teachers misunderstood his theory and overemphasized the importance of recitation method in English learning (Cai, 2005). On the other hand, under the awful pressure of Gaokao system in China, senior high school students become utility knowledge learners and chase high scores in examination which tends to be a popular demand for most English teachers. Accordingly, large amounts of English writing formwork phrases have been created and incorporated into English courses, even in authentic English reference books of IELTS (International English Language Testing System) published in China. In terms of these materials, the researcher found that the most frequent employment of that formwork concentrates on transitions, frame markers (e.g. sequencers and topicalizers), and code glosses which leads to higher identification in the test. However, as data shown in Figure 4.1, endophoic markers are identified the least in tests that means students do not familiar with reminders about information provided ealier as well as announcements of materials coming later.

\subsubsection{Features of Lower Oral Proficiency}

\section{Learners}

As can be seen from the following Figure2, similar to higher oral proficiency English learners, the most frequent identified markers are still attributed to frame markers (account for $20 \%$ of total), code glosses (account for $16 \%$ of total) and transitions (occupy 16\% of total); however, validity markers, such as boosters and hedges (only $3 \%$ and $4 \%$ of total respectively) tend to be extremely low in this group of students. 


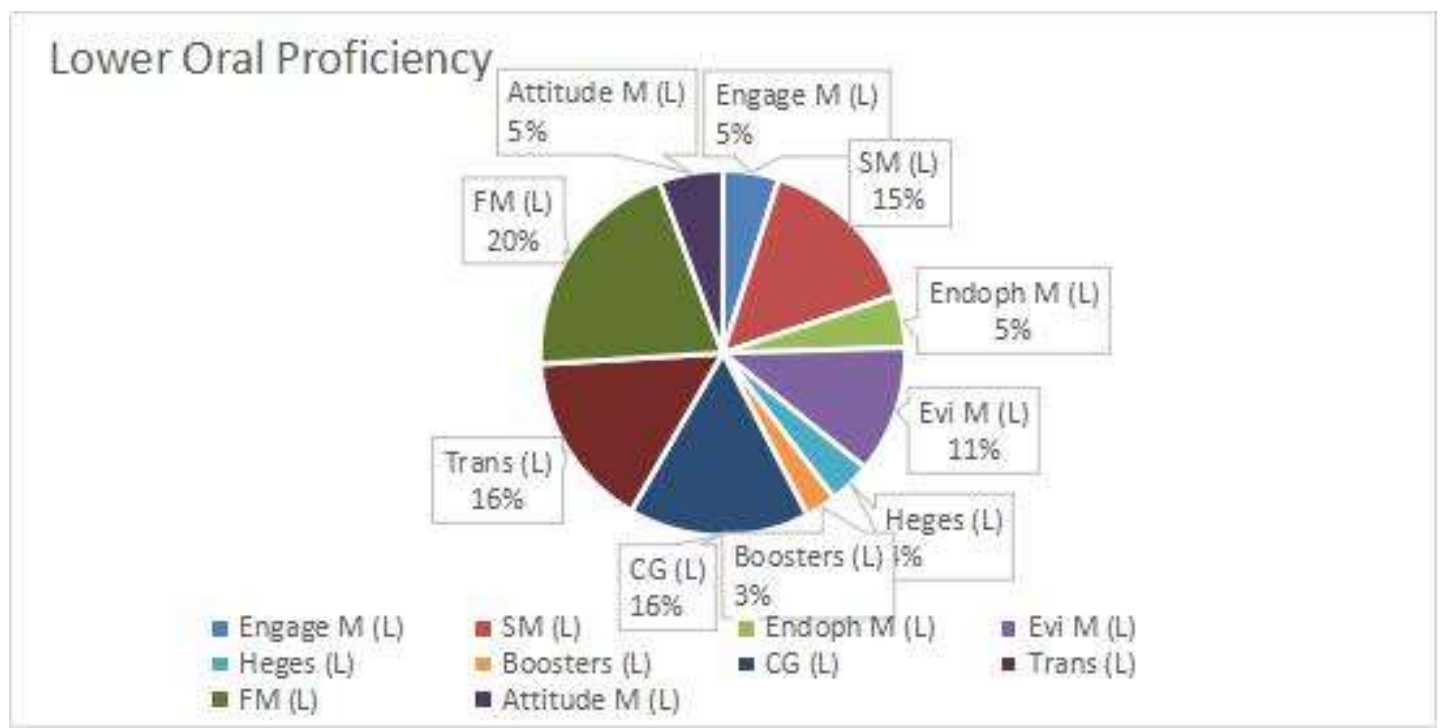

Figure 2: Proportion of identified metadiscourse markers in the test

According to Vande Kopple, validity markers, such as hedges, emphatics (boosters in this research) can be used to indicate how we assess the probability or truth of the propositional content people express and to show how people committed to that assessment (Vande Kopple, 2002). However, there is an obvious deficiency for Shandong English majors with lower oral proficiency to identify such kinds of metalinguistic resources. This may be because, compared with higher oral proficiency students poor oral quality informants are more inclined to express a strong authentic persona which means stress their existence and show less negotiation with others in conversation. By the same token, they are not able to realize the euphemism strategy of hedges in texts as informants with higher oral proficiency do.

\subsubsection{A contrast of identified metadiscourse types with different oral proficiency}

In order to explore students' MIA in terms of different oral proficiency of the informants, the quantities of each type of metadiscourse in the test are collected and the results are illustrated in Figure 3.

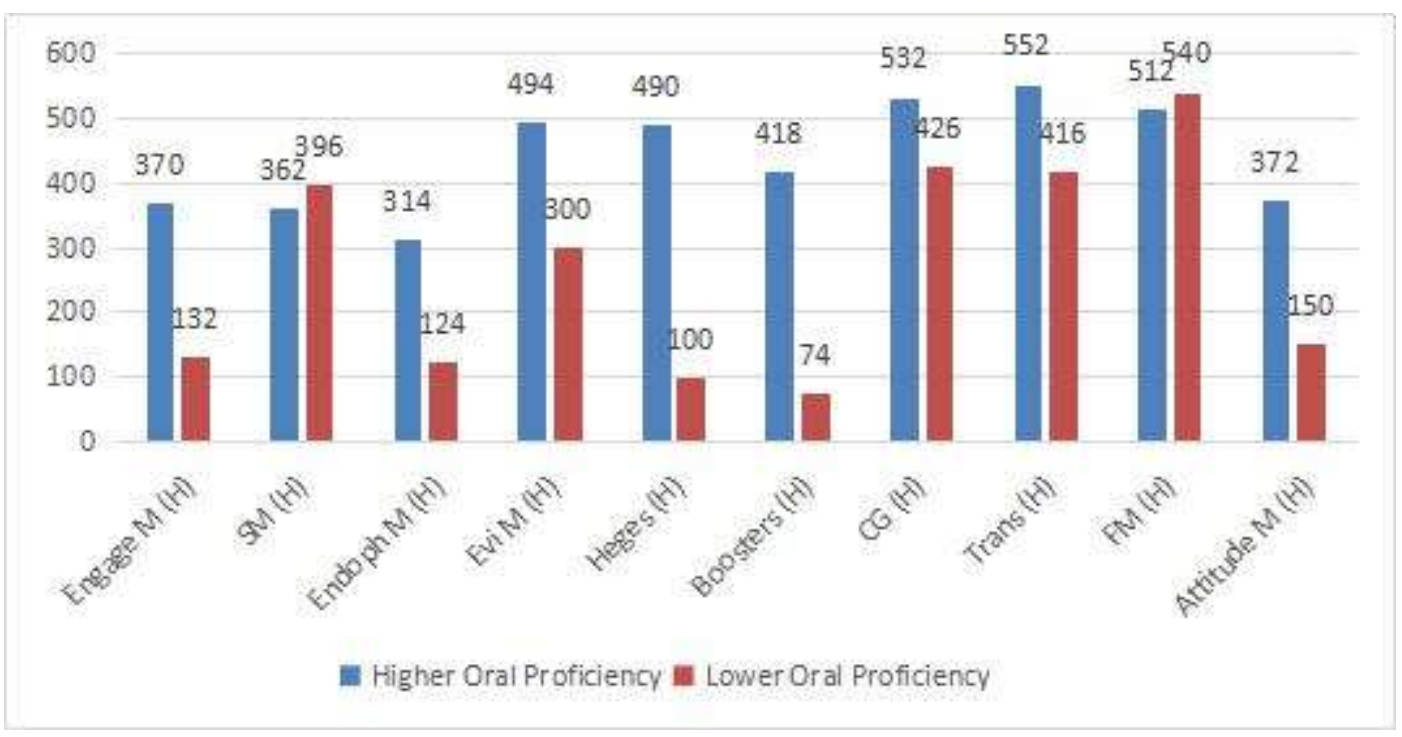

Figure 3: Each type of identified metadiscourse of the two groups 
As can be seen in the above bar graph, differences on quantities of each type of identified metadiscourse in two groups of informants have presented here clearly. The most obvious differences tend to be markers including hedges (390 discrepancy), boosters (344 discrepancy), attitude markers (222 discrepancy) in interactional metadiscourse; by the same token, engagement markers (238 discrepancy) as well as evidentials (194 discrepancy) in interactive metadiscourses are also shown as significant differences in this figure.

More specifically, if we analyze each type of metadiscourse markers identified by two groups of Shandong English majors, more findings can be discovered in the following.

Hedges, such as 'possible', 'are likely to' in this research account for the most obvious difference in MIA of different oral proficiency English majors (490 compared with 100). Hedges, as Halliday (1994) pointed out that aims to alleviate the certainty of the message in conversation with which to keep important interactional negotiation in mutual communication. Strong identification of hedges as shown in the above figure leads to higher oral proficiency is in accordance with many previous researches (e.g. Lin, 2012; Sun, 2012) that emphasized the importance of this kind of metadiscourse employed in conversation. Moreover, it is interesting to note that hedges can also reflect what Brown and Levinson called Face Threatening Theory in 1978. Therefore the identification of hedges can be thought as an effective device to mitigate face threatening of speakers and then further improving friendly atmosphere of their oral output.

Followed by hedges, boosters (418 compared with 74) and evidential markers (494 compared with 300) are continued to be presented the big distinction between two groups of informants in this research. Boosters and evidential markers companied with hedges are belonging to what many linguists called 'validility markers' (e.g. Vande Kopple, 1985; Kong \& Xin, 2009). They express the validity of messages speakers intend to convey. Boosters tend to express certainty and authority to the propositional materials; while evidential markers try to sensitize the speakers that what they expressed have a truth value. Accordingly understanding functions of such kind of metadiscourse is beneficial for the success of oral communication. Meanwhile knowing such kind of metadiscourse can also encourage English majors to keep an appropriate tone in conversation that neither seems to too arrogant nor too indecisive, which leads to higher oral quality in examination.

Above all, it is also worth mentioning that there is a significant correlation between MIA and Oral proficiency. The results can be shown by particular employment of SPSS (independent T-test) in the following Table 3 which further confirms the analysis above.

Table 3: Statistic results of metadiscourse scores

\begin{tabular}{|c|c|c|c|c|c|}
\hline & N & Minimum & Maximum & Mean & Std. Deviation \\
\hline High & 60 & 68.00 & 80.00 & 73.6000 & 2.76295 \\
Low & 60 & 39.00 & 51.00 & 44.3000 & 2.78190 \\
Valid N (listwise) & 60 & & & & \\
\hline
\end{tabular}

The data shows that MIA of higher oral proficiency English learners (Mean 78.6000) tends to be stronger than those of lower oral proficiency learners (Mean 44.3000). From this respect, it is noted that Shandong English majors with higher oral quality can identify more quantities of metadiscourse markers. More importantly, under the utilization of inferential $t$-test in the following Table 4, we can corroborate that oral proficiency of students definitely affects their MIA in oral texts as for $P$-value $=0.0039<0.05$; therefore we draw a conclusion that there is significant distinction in MIA of different oral proficiency students, more specifically, higher oral performance they have, the better MIA they are inclined to show.

Table 4: The Independent T-test of Metadiscourse Scores

\begin{tabular}{|l|c|c|c|c|c|c|c|}
\hline Coefficients & $\begin{array}{c}\text { Standard } \\
\text { Error }\end{array}$ & t Stat & P-value & Lower 95\% & Upper 95\% & $\begin{array}{c}\text { Lower } \\
\mathbf{9 5 . 0 \%}\end{array}$ & $\begin{array}{c}\text { Upper } \\
\mathbf{9 5 . 0 \%}\end{array}$ \\
\hline 0.26544021 & 0.1256680 & 2.1122327 & 0.0389834 & 0.0138882 & 0.5169921 & 0.0138882 & 0.516992 \\
\hline
\end{tabular}




\section{Conclusion}

Taking account of previous metadiscourse research, the current study is designed to further explore the group differences and relationships of MIA among Chinese English majors in Shandong Province with their different oral proficiencies. Firstly, by collecting and classifying metadiscourse testing results of all informants, it is detected that the overall level of MIA of Shandong English majors is not as satisfying as their oral proficiency. Only approximately $50 \%$ of metadiscourse markers in the test are identified by the informants. This is why instruction in metadiscourse knowledge to Shandong English majors is urgently required in college classes at the current time. Secondly, by comparing different types of identified metadiscourse markers with the assistance of computer software and SPSS, it is found that there are obvious differences in their MIA which correlate with oral proficiency level. Interactive metadiscourse are identified more easily than interactional metadiscourse by Shandong English majors in oral context materials due to typical 'knowledge-telling' features of most Chinese academic writings and textbooks. Also, the distribution of identified metadiscourse among higher oral proficiency students is balanced than lower oral proficiency students. This means English majors with higher oral quality can identify more types of metadiscourse markers in oral materials than the other side.

As can be seen from above that Shandong English majors do not show great MIA to English and their identification ability on different types of metadiscourse is also unbalanced that they are inclined to recognize less quantity and monotonous types of metadiscourse in discourse. If students are familiar with metadiscourse devices in oral communication, it would be helpful for them to organize messages and negotiate with their partners, eventually to improve their capabilities in English speaking. Therefore, it is urgent for English teachers to realize the significant functions of metadiscourse could perform in communication, accordingly instruct systematic knowledge of not onl y interactive but also interactional metadiscourse in class, and by this way try to improve consciousness of mutual engagement and effective negotiation between English speakers in oral contexts.

Though the above major findings of this research are meaningful to oral English teaching in Shandong universities, there are still some limitation for the research that only 120 English majors from four universities are investigated in the present research. Small sample size of the informants weakened the effectiveness of the experimental results in this research. More informants are needed to be included in further studies to show more exact MIA of Chinese English majors in Shandong Province.

Appendix

Dear students, for investigating your

identification ability of English oral chunks and developing spoken English teaching in the future, the author designed this test in particular. We promise here to keep your test scores confidential. And the test results are confirmed to have no influence on your academic records. Thank you for your participation and cooperation.

\section{Questionnaire of English Oral Chunks Identification Ability}

Name Gender

TEM-4 Oral Score

\section{There are 37 chunks below, please underline any phrases or words that could play cohesive and coherence roles in the discourse.}

1. On behalf of LP clubs, I'd like to welcome you all here today.

2. Our greatest asset is probably our swimming pool which.... This means there are rarely more than a couple of people at a time in each lane.

3. ..., which means you can enjoy something of the open-air experiment on warmer days.

4. One thing all our members appreciate about us is that we take every good care of them.

5. We provide robes and hairdryers ... and it's very important to remember...

6. And according to the legends of these communities ...

7. .... Because of this, it has always been highly regarded by...

8. There is great concern for... since it is estimated that...

9. The best way to protect... of their forest environment - in other words, their ecosystem...

10. All these influences ... were fragile by the fact that reproduction...

11. An important part of your talk should be the radical theory Heyerdahl formed from...

12. Up until that time of course, academics 
had believed that..

13. It was an incredibly risky journey...

14. ..., he certainly left a lasting impression on...

15. Research has shown that the goals we...

16. Typical examples that will attract and retain staff are...

17. Above all they'll need great skills in leadership ...

18. One trend that...is.... Instead, more and more people...

19. Well, Obviously its purpose is to...

20. I'd like to tell you about four which are currently being adopted by...

21. She helped us work out exactly what to do, for the production. And that made me feel better.

22. Well, she found these articles from the $1950 \mathrm{~s} . .$.

23. Self-regulatory focus theory is.... He says that a person's focus at...

24. Now that I have talked about...

25. .... This will then be reviewed at the end of the...

26. They consider their obligations to others. As a result, they...

27. .... Here are just a few highlights....

28. The next recommended visit is to...

29. Today we're going to look at an important area of..., namely nanotechnology.

30. First, there is.... Second, there is...

II. Please underline linguistic segments that could promote discourse cohesion and coherence, no matter phrases, words or sentences.

Material A

Good morning. In the last few lectures I've been talking about the history of domestic building construction. But today, I want to begin looking at some contemporary, experimental designs for housing. So, ...start with a house which is constructed more or less under the ground...one of the interesting things about this project is that the owners-both professionals but not architects - wanted to be closely involve... Their chief aim was to create somewhere that was as environmentally-friendly as possible. But at the same time they wanted to live somewhere peaceful - they'd both grown up in a rural area and disliked urban life.

So, the first thing they did was to look for a site. And they found a disused stone quarry in a beautiful area. The price was relatively low, and they liked the idea of .... As it was, the quarry was an ugly blot on the landscape, and it wasn't productive any longer, either.

They consulted various architects and looked at a number of designs before finally deciding on one. As I've said, it was a design for a sort of underground house, and it was built into the earth itself, with two storeys. The north, east and west sides were set in the earth, and only the slopping, south-facing side was exposed to light. There were also photovoltaic tiles fixed to the top and bottom of this slopping wall. These are tiles that are designed to store energy from the sun. And the walls had a layer of foam around them too to increase the insulation.

Now, what is of interest to us about this project is the features which make the building energy-efficient....in addition, the special tiles on the outside convert energy from the sun and generate some of the house's electricity. In fact, ... and that the owners will be able to sell some to the national grid.

As well as that,... recycled materials have been used. For example, the floors are made of reclaimed wood. And the owners haven't bought a single item of new furniture - they just kept what they already had. And then there's the system...

It's true that the actual construction of the house was harmful to the environment, mainly because they ...one of the biggest sources of carbon dioxide in manufacturing. And, as you know, this is very damaging to the 
environment. In total, the house construction has increased 70 tons of carbon dioxide into the air. Now that's a frightening thought. However, once the initial 'debt' has been cleared-and it's been calculated that this will only take fifteen years - this underground house won't cost anything - environmentally I mean-... it is run in a way that is completely environmentally friendly.

... eco-housing like this is likely to become...

\section{Material B}

Woman: Can I help you?

Man: $\quad$ Yes, I've just moved to this area with my wife and children and I'd like to know where we can all register with a doctor at a Health Center.

Woman: Okay. Well, there's Doctor Green at The Harvey Clinic. We always recommended her for babies...

Man: Oh... actually my youngest child is five...it wouldn't be any good for us.

Woman: And it's particular good if you're busy during the day... You can register with Doctor Gormley, that's G-O-R-M-L-E-Y. ...

Man: $\quad$ Oh yes, I think I know the road... Woman: Em... there are ...some small charges that doctors make. Let me see what it says about the Shore Lane Center; if you need to be vaccinated before any trips abroad, you won't have to pay for this. ... Shore Lane is hoping to this soon-I think ... start with acupuncture. And finally, if you need to prove you're healthy or haven't had any serious injuries before a new employer will accept you, you can get a free fitness check-up there... you'd most likely ...pay for insurance medicals though.

Man: $\quad$ Okay, thanks

\section{REFERENCES}

[1] Adel, A. Metadiscourse in L1 and L2 English [M]. Amsterdam \& Philadelphia: John Benjamins. 2006.
[2] Beauvais, P. A speech act theory of metadiscourse [J]. Written Communication, 1989, 6 (1): 11-30.

[3 Bruner, J. Pragmatics of language and language of pragmatics [J]. Social Research, 1984, 51, 969-984.

[4] Crismore, A. Talking with Readers: Metadiscourse as Rhetorical Act [M]. New York: Peter Lang. 1989.

[5] Crismore, A., Markkanen, B. \& Stteffensen, M.S. Metadiscourse in persuasive writing [J]. Written Communication, 1993, 10, 39-71.

[6] Dilts, D. \& A. J. Murphy. Style: Ten Lessons in Clarity and Grace [J]. Technical Communication, 2005, 52 (3): 396-397.

[7] Halliday, M.A.K. Explorations in the Functions of Language [M]. London: Edward Arnold. 1973.

[8] Halliday, M.A.K. An Introduction to Functional Grammar (2 ${ }^{\text {nd }}$ edn.). London: Edward Amnold. 1994.

[9] Hamre, B. K. \& R. C. Pianta. Teaching through Interactions: Testing a Developmental Framework of Teacher Effectiveness in over 4,000 Classrooms [J]. Elementary School Journal, 2013 (3): 461-487.

[10] Hyland, K. Metadiscourse: Exploring Interaction in Writing [M]. Continuum, London/NY Press. 2005. Hyland, K. Disciplinary Discourses: Social Interactions in Academic Writing [M]. London: Longman.2000.

[11] Hyland, K. Talking to Students: Metadiscourse in Introductory Coursebooks [J]. English for Specific Purposes, 1999, 18, 3-26.

[12] Hyland, K. \& P. Tse. Metadiscourse in academic writing: a reappraisal [J]. Applied Linguistics, 2004, 25, 156-177.

[13] Ifantidou, E. The Semantics and Pragmatics of metadiscourse [J]. Journal of Pragmatics, 2005, 37 (9): 1325-1353.

[14] Intaraprawat, P. Metadiscourse in Native English Speaker's and ESL Students Persuasive Essays [D]. Illinois State University, Normal, IL. 1988.

[15] Keller, E. Gambits: Conversational strategy signals [J]. Journal of Pragmatics, 1979, 3, 219-228.

[16] Kumpf, E.P. Visual metadiscourse: Designing the considerate text $[\mathrm{J}]$. Technical Communication Quarterly, 2000, 9(4): 401-424.

[17] Lautamatti, L. Observations on the development of the topic in simplified discourse [J]. Textlinguistics, 
Cognitive Learning and Language Teaching, 1978, 71-104.

[18] Leila Khabbazi-Oskouei. Propositional or non-propositional, that is the question: A new approach to analyzing 'interpersonal metadiscourse' in editorials [J]. Journal of Pragmatics, 2013, 47, 93-107.

[19] Meyer, B. The Organization of Prose and its Effects on Memory [M]. Amsterdam: North-Holland. 1975.

[20] Mao, L. R. I conclude not: toward a pragmatic account of Metadiscourse [J]. Rhetoric Review, 1993, $11,265-289$.

[21] Mauranen, A. Contrastive ESP rhetoric metatext in Finnish-Englsih Economics texts [J]. Englsih for Specific Purposes, 1993, 12, 3-22.

[22] Paul, G. \& F. Van de Velde. Interactional metadiscourse in research article abstracts [J]. Journal of English for Academic Purposes, 2010, 9, 128-139.

[23] Plakans, L. Metadiscourse: Exploring interaction in writing [J]. Reviews/English for Specific Purposes, 2007, 26, 515-524.

[24] Reza Abdi. Interpersonal metadiscourse: an indicator of interaction and Identity $[\mathrm{J}]$. Discourse Studies, 2002, 4, 139-145.

[25] Rossiter, Jr. Theories of Communication [M]. Oxford: Oxford University Press. 1974.

[26] Schiffrin, D. Metatalk: Organizational and Evaluative Brackets in Discourse. Sociological Inquiry [J]. Language and Social Interaction, 1980 (50): 199-236.

[27] Sinclair, J. Planes of discourse [N]. Honour of Ramesh Mohan, 1981, 70-89.

[28] Ting Li \& Wang Sue. Metadiscourse repertoire of L1 Mandarin undergraduate writing in English: A cross-contextual, cross-disciplinary study [J]. Journal of English for Academic Purposes, 2012, 11, 345-356.

[29] Thompson, G. \& Thetela, P. The sound of one hand clapping: The management of interaction in written discourse [J]. TEXT, 1995 (15): 103-127.

[30] Ting L. \& Wharton, S. Metadiscourse repertoire of L1 Mandarin undergraduates writing in English: A cross-contextual, cross-disciplinary study [J]. Journal of English for Academic Purposes, 2012, 11, 345-356.

[31] Vande Kopple, W. Some exploratory discourse on metadiscourse $[\mathrm{J}]$. College Composition And Communication, 1985, 36, 82-93.

[32] Vande Kopple, W. Metadiscourse, discourse, and issues in composition and rhetoric [A]. In Barton, E. \& G. Stygall (eds.). Discourse Studies in Composition [C]. New Jersey: Hampton Press. 2002.

[33] Williams, R. Style: Ten Lessons in Clarity and Grace [M]. Boston: Scott Foresman. 1981

[34] Cai Jigang. Reflections on College English Teaching $[\mathrm{J}]$. Foreign language teaching and research, 2005 (2): 83-91.

[35] Cheng Xiaoguang. Theory and application of sub language $[\mathrm{J}]$. Foreign language and foreign language teaching, 1999 (9): 4-7.

[36] Cheng Xiaoguang. The study of sub language [M]. Dalian: Liaoning Normal University Press, 1997.

[37] Cheng Xiaoguang, Jiang Hui. Metadiscovery: sub language, meta discourse or meta discourse? [J]. Foreign language and foreign language teaching, 2008 (5): 45-48.

[38] Cheng Xiaoguang, Jiang Hui. A study on the role of sub language in College English writing $[\mathrm{J}]$. Foreign languages, 2004 (5): 68-79.

[39] Ding Shan. A review of metadiscourse research [J]. Contemporary education theory and practice, 2009 (2): 154-156.

[40] Fang Dan, Liu Xin. A review of metadiscourse classification [J]. Journal of culture, 2015 (4): 193-195.

[41] Feng Zongxin. Metalanguage in Linguistics and its research status $[\mathrm{J}]$. Foreign language teaching and research, 2005 (6): 403-410.

[42] Gao Ming. Application of metadiscourse theory in College English Writing Teaching [D]. Lanzhou: Lanzhou University of technology. 2012.

[43] Guo Xiaoning. A study on the ability of Chinese English majors to identify prefabricated lexical chunks [D]. Changchun: Northeast Normal University, 2009.

[44] Han Meizhu. Metadiscourse, corpus and college oral English Teaching [J]. Foreign languages, 2009 (3): 32-36.

[45] he Anping. A corpus based approach to "marker chunks" in spoken English [J]. Foreign language teaching theory and practice, 2011 (1): 25-37. 
[46] Huang Dandan. Meta discourse study of oral academic discourse [D]. Guangzhou: South China University of technology, 2014.

[47] Huang Guowen. Summary of discourse analysis [M]. Changsha: Hunan Education Press, 1991.

[48] Kong Rui, Xin Xin. An Empirical Study on the use of Metadiscourse in Chinese students' oral English [J]. China English teaching, 2009 (1): 52-64.

[49] Li Tianxian, Pang Jixian. The interactive function of Metadiscourse in academic writing [J]. Foreign language teaching and research, 2009 (5): 266-271.

[50] Li Zuowen. The construction and embodiment of discourse on context [J]. Foreign languages, 2001 (3): 44-50.

[51] Lin Meizhen. The evaluation function of English Interactive metadiscourse based on corpus analysis $[\mathrm{J}]$. Journal of Shenyang University, 2012 (6): 93-96.

[52] Liu Qi. A review of meta discourse theory [J]. Journal of Hebei University of engineering, 2015, 1, 103-105.

[53] Si bingyue. An empirical study of college oral English teaching based on metadiscourse theory [J]. Journal of foreign languages, 2014 (1): 121-124.

[54] Tang Jianping. A review of metadiscourse research [J]. Shandong foreign language teaching, 2010 (1): 96-101.

[55] Sun Mingming. Metadiscourse awareness training of strategies for improving oral communication ability of English Learners [J]. Journal of education of Jilin Province, 2012 (10): 67-68.

[56] Wang lifeI, Zhou Dandan. 12 years of oral English research in China: review and current situation [J]. Foreign language circle, 2004 (6): 7-14.

[57] Wen Qiufang. Research methods and thesis writing of Applied Linguistics [M]. Beijing: foreign language teaching and Research Press, 2004.

[58] Xin Xin. Research on the correlation between metadiscourse and oral quality $[\mathrm{J}]$. Foreign language teaching research, 2009 (7): 90-92.

[59] Xu Haiming. Metadiscourse: Theory and demonstration from a cross-cultural perspective [M]. Nanjing: Southeast University Press, 2001.

[60] $\mathrm{Xu}$ Jun. on the scope and classification of metadiscourse [J]. Contemporary linguistics, 2006 (4): $345-353$

[61] Zhang Yuying. A study on the correlation between the recognition ability of prefabricated chunks and the level of second language $[\mathrm{J}]$. Foreign language circles, 2008 (3). 